\title{
鼻腔腫瘍34例の検討
}

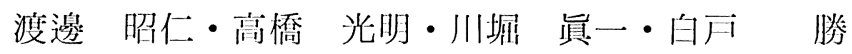 \\ 中村 晃・熊井 恵美 - 野中 聡 - 長島 泰行 \\ 金井 直樹 - 井本 祥子 - 谷田 光弘 - 海野 徳二
}

\section{Clinical Study of Nasal Cavity Tumors}

\author{
Akihito Watanabe, Mitsuaki Takahashi, Shinichi Kawabori, \\ Masaru Shirato, Akira Nakamura, Megumi Kumai, \\ Satoshi Nonaka, Yasuyuki Nagashima, Naoki Kanai, \\ Shoko Imoto, Mitsuhiro Tanida and Tokuji Unno \\ (Asahikawa Medical School)
}

We examined 34 patients with tumors of nasal cavity between 1976 and 1986 . There were nineteen benign tumors (three papillomas, one pleomorphic adenoma, ten hemangiomas, two angiohemangiomas, two leiomyomas and one benign nonepitherial tumor) and fifteen malignant tumors (three squamous cell carcinomas, one adenocarcinoma, seven malignant lymphomas, two malignant melanomas, one hemangiopericytoma and one case suspected of angiosarcoma). All benign cases were treated with global resection, with no recurrence to date. In malignant cases, three squamous cell carcinoma were treated with combined therapy (preoperative irradiation and resection) and one adenocarcinoma was treated with resection only. Three of these patients survived without tumor. We treated eleven malignant nonepitherial tumors. Six of these patients survived more than two years.

Key words: nasal cavity, benign tumor, malignant tumor

\section{はじめに}

耳鼻咽唉科において报う鼻腔腫瘍は必ずしも

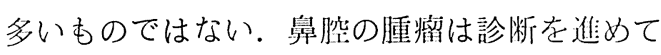
いくうちに上顎洞や飵骨洞等の副鼻㨫由来であ ったり，鼻腔か副鼻腔のどちらが原発か判断に 迷うものも少なくない，また，鼻腔脙璌の特徵 の一つは副鼻腔に比して病理組織が多彩である と云われている，さらに䦩腔腫演の治療法につ いては，いまだ確立されたものはない.
今回我々は，当科の開設された科和51年11月 より炤和 61 年 1 月までの約 9 年間において術前 榆查及び手術洔に鼻腔腫瘍と確認し，病理組織 学的に分類のできた34症例につき，当科におけ る治療法之予後について検討し，あわせて文献 的考察を加えたので報告する.

\section{症例}

詔和 51 年 11 月の当科開設以米約 9 年間に当科 外来を曼搒し術前検查（鼻鏡沂见，レントゲン 


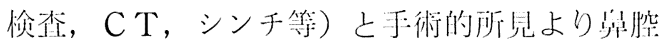

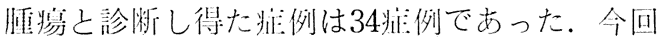

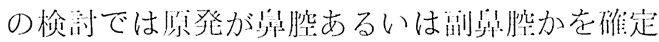
できなかったむのや Wegener 肉芽腫症，進行

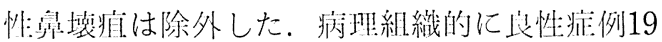
例，覀性:将:例15例であり，その比は約 $1.3: 1$ であった。

\section{1. 性汾}

34例男性21例，女性13例之男性に多くみら れた。应性瑟性别では，良性症例は男女比10例 刘 9 例之ほぼ同数であった。覀性症例は11例対 4 例と男性が 2 㒉以上多くみられた。

2 . 作榆 (図 1 )
年柃については艮に性症例は 9 才から74才と幅 広く分们して扣り，平均 45.3 才であった。一

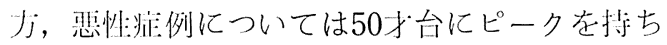
全例 30 才台以上であり，平均58.1才であった。 これら是性悪性症例全体の平均年喻は50.9才で

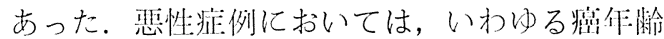
に一致していた。

\section{3 . 自觉症状 (図 2 )}

瑟性症例においては良性症例に比して多彩な 症状がみられた。その内訳は, 良性症例では鼻 出血が 12 例, 腫瘤の自営が 8 例, 鼻閉感が 7 例, 鼠游が 3 例, 臭内漧燥感が 1 例であった。 一厅, 琹性症例では舅閉感が14例, 鼻出血が 7

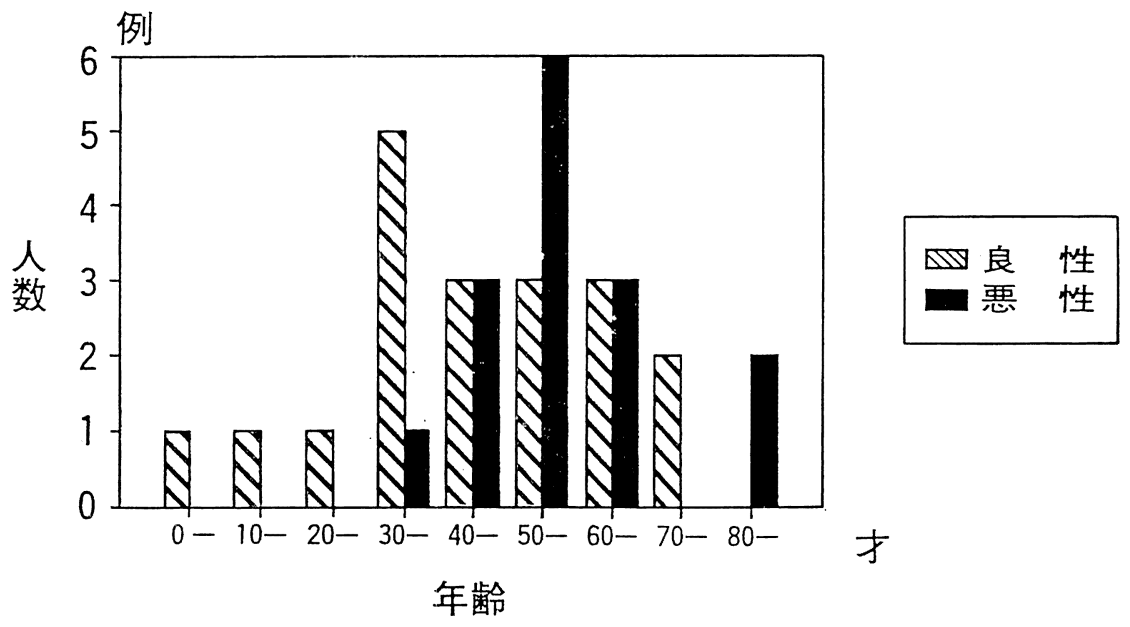

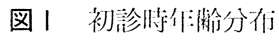

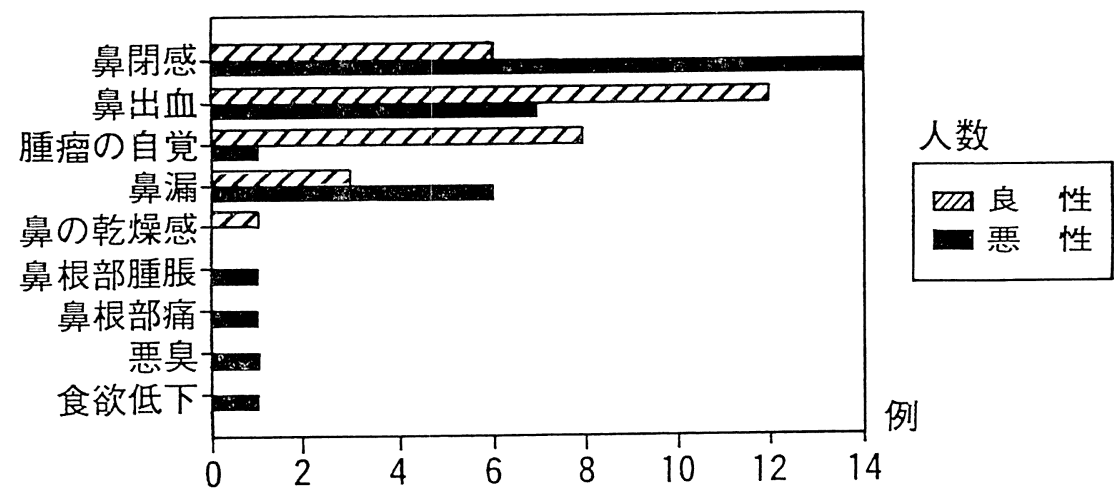

図 2 自觉症状 
例, 鼻漏が 6 例, 腫瘤の自覚は 1 例みられた。 また，良性症例ではみられなかった鼻根部腫 脹, 鼻根部痛, 悪臭, 食欲低下が各 1 例づつみ られた。

\section{4. 腫瘍部位及び病理組織}

良性症例は病理組織学的に多彩であり，上皮 性腫瘍 4 例，非上皮性腫瘍15例であった。 上皮 性腫瘍においては乳頭腫 3 例であり, 組織学的 分類では inverted type 2 例, mixed type 1 例であった。発生部位は中鼻道己鼻前庭にみら れた。多形腺腫の 1 例は鼻中隔より発生してい た。一方，非上皮性腫瘍にては，血管腫が 10 例 と多くみられた。血管腫を組織学的分類に従っ て分けると capillary type 9 例, cavernus type 1 例であった，発生部位は下甲介，鼻中隔 に各 4 例之多くみられ，他に鼻前庭に 2 例之み られた，その他，血管線維腫は下甲介と中鼻道 にみられ，平滑筋腫は 2 例之も鼻底部にみられ
た。病理学的㡣断が不明の 2 症例は, 病理組織 学的に非上皮性良性腫瘍と診断されたが確定診 断には至らなかった症例で，下甲介部から発生 していた（表1）.

琹性症例では上皮性腫瘍 4 例，非上皮性腫瘍 11例がみられた。上皮性腫痬の内訳として扁平 上皮癌 3 例で全て非角化型のものであった．発 生部位は中鼻道 2 例，下甲介 1 例であった。症 例 1 は初診侍に頸部リンパ節は触れなかったも のの治療中には両侧頸部リンパ節を触知した。 症例 2 は前医にて頸部リンパ節生検を行った後 に当科初診した症例で, 初部恃両側頸部リンパ 邻転移を認めていた。症例 3 は下甲介より発生 し頸部リンパ節を触知しなかった．腺癌の 1 例 （症例 4 ）は中用介より発生したもので頸部り ンパ節を触知しなかった（表 2 ）。

非上皮性覀性腫晹としては悪性リンパ腫が 7 例にみられた。これら覀性リンパ腫は全て

表। 良性腫塬の病理組織と発生部位

\begin{tabular}{|c|c|c|c|c|c|c|c|}
\hline & & 下甲介 & 中舁道 & 自底部 & 男中隔 & 畺前庭 & \\
\hline $\begin{array}{l}\text { 上 } \\
\text { 粟 } \\
\text { 性 }\end{array}$ & $\begin{array}{l}\text { 乳頭腫 } \\
\text { 多形腺腫 }\end{array}$ & & 1 & \multicolumn{3}{|c|}{1} & $\begin{array}{l}3 \\
1\end{array}$ \\
\hline $\begin{array}{l}\text { 非 } \\
\text { 上 } \\
\text { 皮 } \\
\text { 性 }\end{array}$ & $\begin{array}{l}\text { 血管腫 } \\
\text { 血睯;線維腫 } \\
\text { 平滑筋腫 } \\
\text { 不 明 }\end{array}$ & $\begin{array}{l}4 \\
1 \\
1\end{array}$ & 1 & 2 & 4 & 2 & $\begin{array}{r}10 \\
2 \\
2 \\
1\end{array}$ \\
\hline & 計 & 6 & 2 & 2 & 5 & 4 & 19 \\
\hline
\end{tabular}

表 2 上皮性覀性腫湯

\begin{tabular}{|c|c|c|c|c|}
\hline 症 & 病理組織 & $\begin{array}{l}\text { 頸部リンパ } \\
\text { 節転移 }\end{array}$ & 治療 方 法 & 転 \\
\hline 症例 1. 43才男 & 扁平上皮癌 & $\begin{array}{ll}\text { 初診時 } & (-) \\
\text { 治燎中 } & (+)\end{array}$ & 放射線一手術 & 4 年10か月生存 \\
\hline 症例 2. 56才男 & 扁平上皮癌 & 両 侧 $(+)$ & 放射線一手術一化療 & 4 汃月死亡 \\
\hline 症例 3. 55才男 & 扁平上皮癌 & $(\rightarrow)$ & 放射線一手術 & 7 か月生存 \\
\hline 症例 4. 47才男 & 腺癌 & $(\rightarrow)$ & 手術 & 2 年 6 加月生存 \\
\hline
\end{tabular}


非ホジキンリンパ腫であり組織学的分類では diffuse type に属するものであった。 症例 5 は初診時肉眼的には右下甲介にある程度限局し ていたと思われたが治療を拒否し，10ケ月後に 治療を開始した時には右鼻腔全体に腫瘤が浸澗 していた状態であった，又，右頸部リンパ節も 触れるようになった。症例10は左鼻腔と肺門部 リンパ節に $\mathrm{Ga}$ の取り込みが認められた症例 であり, 症例 6,7 は鼻腔のみの腫瘤存在を考
えて治療開始し治療中に腹部腫瘤が発見された 症例であり，てれら $6,7,10$ の 3 症例はいず れ屯全身型を示した。症例 $8 ， 9 ， 11$ はいずれ 屯鼻腔にのみ限局した症例であった（表 3 ）.

その他として覀性黒色腫は下甲介と右鼻腔よ り発生した 2 例があり, 初診時にはいずれも頸 部リンパ側を触知しなかった。他には血管外皮 腫が右中甲介より発生し，血管肉腫疑いが右下 甲介より発生していた。2 例とも頸部リンパ胼

表 3 非上皮性悪性腄湜

1）悪性リンパ腫

\begin{tabular}{|c|c|c|c|c|}
\hline 症 & 病 理組 織 & Stage 分類 & 治療方法 & 転 帰 \\
\hline 症例 5. 39才男 & 非ホジキンリンパ腫 & $\begin{array}{l}\text { Stage } 2 \\
\text { (頸部リンパ節) }\end{array}$ & 放射線 & 3年4か月 \\
\hline 症例 6. 69才女 & 非ホジキンリンパ腫 & $\begin{array}{l}\text { Stage 1-4 } \\
\text { (腹部腫瘤) }\end{array}$ & 放射線一化療 & $\begin{array}{l}\text { 2か月 } \\
\text { 死亡 }\end{array}$ \\
\hline 症例 7. 51才女 & 非ホジキンリンパ腫 & $\begin{array}{l}\text { Stage 1-4 } \\
\text { (腹部腫瘤) }\end{array}$ & 放射線一化療 & $\begin{array}{l}\text { 7か月 } \\
\text { 死亡 }\end{array}$ \\
\hline 症例 8. 52才男 & 非ホジキンリンパ腫 & Stage 1 & 放射線一化療 & $\begin{array}{r}\text { 3年6か月 } \\
\text { 生存 }\end{array}$ \\
\hline 症例 9. 54才女 & 非ホジキンリンパ腫 & Stage 1 & 放射線一化療 & $\begin{array}{r}\text { 2年8か月 } \\
\text { 生存 }\end{array}$ \\
\hline 症例10.62才男 & 非ホジキンリンパ腫 & $\begin{array}{l}\text { Stage } 2 \\
\text { (肺門部リンパ節) }\end{array}$ & 化療一放射療 & $\begin{array}{l}\text { 3か月 } \\
\text { 死亡 }\end{array}$ \\
\hline 症例11. 88才女 & 非ホジキンリンパ腫 & Stage 1 & 放射線 & $\begin{array}{r}\text { 1年2か月 } \\
\text { 生存 }\end{array}$ \\
\hline
\end{tabular}

表 4 非上皮性恶性腫鲩

2) その他

\begin{tabular}{|c|c|c|l|r|}
\hline 症 例 & \multicolumn{1}{|c|}{ 病理組織 } & リンパ節転移 & \multicolumn{1}{|c|}{ 治 療 方 法 } & 転 帰 \\
\hline 症例12.68才女 & 悪性黒色腫 & $(-)$ & 手術 & $\begin{array}{r}\text { 2年1か月 } \\
\text { 死亡 }\end{array}$ \\
\hline 症例13. 56才男 & 悪性黒色腫 & $(-)$ & 手術一化療十免疫 & $\begin{array}{r}\text { 3年4か月 } \\
\text { 死亡 }\end{array}$ \\
\hline 症例14.84才男 & 血管外皮腫 & $(-)$ & 化療一手術 & $\begin{array}{r}11 \text { か } \\
\text { 生存 }\end{array}$ \\
\hline 症例15. 47才男 & 血管肉腫疑 & $(-)$ & 手術一手術 & $\begin{array}{r}\text { 6年6か月 } \\
\text { 生存 }\end{array}$ \\
\hline
\end{tabular}


を触知しなかった（表 4).

\section{5. 治療方法}

良性症例に求いては全例外科的摘出術を施行 した。診断の為に生検術を行ったものは 3 例あ り，他の症例は生検を兼て全摘術を行った。 尚，摘出術の際にはできるだけ周围の正常組織 む含めた大きな切除を心掛けた。しかし，血管 腫の 1 例において残存あり再度手術を行い完全 に摘出した.

悪性症例は悪性黑色腫の 2 例を除き全例に生 検を行い, 組織診断の後に治療に入った。扁平 上皮癌症例では，原則として術前照射後外科的 切除を行った。尚，初診時に雨倒頸部リンパ饰 転移の涊められた症例（症例 2 ）は化学療法

(Cisplatin, Adriamycin) を加えた。腺癌症 例は外科的切除のみを行った。非上皮性症例の 恶性リンパ腫は $\mathrm{Ga}$ シンチや骨シンチ，超音 波検查等で Stage 分類 (Ann Arbor 分類) 在行い，基本的に Stage 1，2 飞は放射線療法 を中心に行い, Stage 3，4 には化学療法を中 心とした治療を行った。症例によっては放射線 療法と化学療法を組み合わせて行った。恶性黒 色腫は 1 例（症例12）に拈いては外科的切除の みを行った。他の 1 例（症例13）は術前に出血

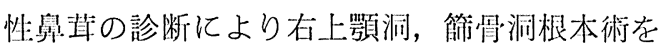
行い, 病理診断にて鼻腔悪性黒色腫の診惭であ った。すぐに凍結手術と右頸部垶清を行った。 術後化学療法 (Dacarbazine (DTIC), Vincrstine (VIC), Nimustine (ACNU), 怂疫療 法 $(\mathrm{BCG})$, 侦餌療法（低フェニルアラニン 位，低チロヂン食）を合わせておてなった。而 管外皮腫症例には外科的切除のみを行い，血管 肉腫疑い症例は最初に Wegener 肉芽腫症をむ 念頭に入れステロイド剂を使い，生検にて血管 肉腫が一番考えられるとのととで外科的切除を 行った.

\section{6 . 予後}

良性症例は全例に外科的摘出術を行い最長 8 年から最短 3 ケ月, 平均 3 年 4 ケ月の経過县察 で再発例は認めなかった。
恶性症例で，上皮性のものは最長 4 年10ケ月 から最短 7 ケ月, 平均 1 年10ケ月の経過観察を 行った。症例 2 は 3 ケ月後に遠隔転移を認め 4 ケ月後に死亡した。症例 $1 ， 3$ は 4 年10ケ月, 7 ケ月の経過にて再発転移をみていない。腺癌 症例（症例 4 ）は 2 年 6 ケ月の経過観察にて再 発転移はなく生存している。

非上皮性症例にては最長 6 年 6 ケ月, 最短 11 ケ月, 平均 2 年 3 ケ月の経過観察を行った。恶 性リンパ腫症例の死亡例をみると, 症例 5 は 3 年 3 ケ月後に再発により死亡した。症例 6,7 はごちらも放射線治療開始後約 1 ケ月で腹部腫 瘤に気付きそれぞれ 2 ケ月， 7 ケ月後に全身に 腫瘤を認め短期間に死亡した。症例10は化学源 法途中にて全身状態琹くなり間質性肺炎を併発 して死亡した．他の 3 例（症例 $8 ， 9 ， 10 ） は$ 予後良好な症例であった。乙れらはいずれむ Stage 1 の限局性にのみ存在した症例であっ た。症例11においては年跉屯考虑して放射線療 法のみであり, 症例 8,9 は放射線治療終了後 化学療法（Vinclistin）をむ加えた症例であっ た。

䜀性黒色腫症例は 2 例とも死亡例であるが症 例 12 は 2 年 1 ケ月後に脳や他の臟器転移により 死亡した。剖検では鼻腔並びに頸部リンパ笛に は腫瘍は存在していなかった。症例13は局所再 発の後に全身転移にて死亡した。血管外皮腫症 例（症例14）は11ケ月の経過観察で再発転移は みられていない。また覍管肉腫疑い症例（症例 15）は 6 年 6 ケ月の経過峴察にて再発転移なく 生存している.

乙れら琹性腫煌の粗生存率は上皮性症例にお いて, 1 年生存率 $2 / 3=66.7 \%, 2$ 年生存率 $2 / 3=66.7 \%, 3$ 年生存梁 $1 / 2=50.0 \%$ で あった。非上皮性に㧍いて, 覀性リンパ腫の成 績は， 1 年生存率 $4 / 7=57.1 \%, 2$ 年生存率 $3 / 6=50.0 \%, 3$ 年生存率 $2 / 4=50.0 \%$ で あった。琹性非上皮性腫湯の予後は， 1 年生存 率 $7 / 10=70.0 \%, 2$ 年生存率 $6 / 9=67.6$ $\%, 3$ 年生存率 $4 / 7=57.1 \%$ であった. 


\section{考察}

鼻腔より発生する腫煌は, 多い屯のではな い，本邦に㧊いては，隈上 ${ }^{1)} の 16$ 年間に 22 例の 報告，また小林ら ${ }^{2)}$ の 13 年間での 31 例の報告が ある. 我々は炤和 51 年 11 月よりの約 9 年間に良 性腫瘍19例, 悪性腫瘍15例の計34症例を経験し た。これらの病理組織は多彩であった。险上 ${ }^{11}$ は副鼻腔まで発生したものまで入れると, 病理 学成書に記載されているあらゆる腫瘍が発生す ると言っても過言ではないと述べている.

当科に打ける34症例の自覚症状は，良性症例 に打いて鼻出血が多くみられた。乙れは良性症 例では血管腫が10例と多く，てのうち 9 例に鼻 出血をみており，てのような病理組織の反映し たものと考えられた。一方，瑟性症例において は，15例中14例之，高率に鼻閉感を訴える症例 が多く悪性腫瘍では腫瘍の增大傾向が速い為と 思われた。

治療法については，当科では良性腫瘍症例は 原則として全例外科的切除を行った。鼻腔に発 生する良性腫瘍は病理組織学的に良性であって 屯術後再発症例の報告も多い。乳頭腫において 戸田ら ${ }^{5)} 2 / 9$ (22.2\%), 御手洗ら ${ }^{6)}$ は27\% の再発がみられたと報告している，又，50\%以

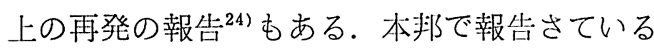
鼻腔原発血管線維腫例にては再発例はないが, 鼻咽腔原発のあのでは，多田ら ${ }^{25)}$ は35\%に，白 憣ら ${ }^{26)}$ は50\%以上に再発があると報告してい る. 我々の症例では平均 3 年 4 ケ月の経過観察 で再発がみられなかった。鼻腔の解剖学的な制 限から充分な切除の困蜼な症例むあるが，良性 腫禓は周囲の正常組織をも含めた充分の籍罒で の外科的切除ができるならば根治的治療が可能 であると考えられた。一方，悪性症例において 上顎癌は三者併用療法が確立。された感がある が，鼻腔悪性腫瘍はいまだ碓立.した治療法はな い。しかし，扇平、上皮癌では外科的治療と放射 線治療の併用療法の報告 ${ }^{12)}{ }^{13)}$ が多い。腺癌はそ の放射線治療あるいは化学療法に抵抗するあの が多く手術療法が原則として行われている。 上
皮性鼻腔悪性腫瘍の生存率は, 酒井ら ${ }^{15)}$ は 1 年生存率 $6 / 9=66.7 \%, 2$ 年生存率 $3 / 7=$ $42.9 \%, 3$ 年生存率 $2 / 6=33.3 \%$, 近藤 ${ }^{12)}$ は 1 年生存率 $12 / 13=92.3 \%, 2$ 年生存率 $11 /$ $13=84.6 \%, 3$ 年生存渄 $9 / 13=69.2 \%$ との報 告がある. 我々の症例屯 4 症例之症例数は少な いものの現在 3 例生存している. 死亡症例（症 例 2 ）は他科で頭頸部領域の検索を行わずに頸 部リンパ晸生検を行った後に数週間後から治療 を開始した症例で，計画性のない生検が予後を 覀くしたと考えられた。転移について近藤らは 13例中 6 例の多くに認めており我々も 4 例中 2 例の半数に認めた。このことより鼻腔の上皮性 瑟性腫癔については術後管理で, 特に頸部リン パ幯を含めた全身の経過钼察が必要である.

悪性リンパ腫は治療法について Stage によ る治療法を行っているが, 近年早い Stage に む化学療法の使用により良好な予後を得たとの 報告 ${ }^{17)}{ }^{18)}$ がある。しかしながら治療法が同じで ありながらむその悪性リンパ腫の原発部位によ り予後が些っており, 鼻腔原発の屯のはワルダ イエル扁桃輸原発のあのに比べると予後悪い.

浜口ら ${ }^{18)}$ は 3 例の鼻腔墨性リンパ腫で 1 年生存 率 $1 / 2=50 \%, 3$ 年生存率 $0 / 2=0 \%$, 浅 野ら ${ }^{27)}$ は舅副鼻腔领域で 1 年生存率 $54 \% ， 3$ 年 生存率 $46 \%$ と報告している. 我々の症例の生存 例を検討すると，いずれむ鼻腔限局の Stage 1 症例が大半を占めて扣り，悪性リンパ腫におい ては鼻腔にのみ存在する限局型は予後良く，早 期に他の遠隔部に屯腫癔の存在するような全身 型は予後腎いと言えよう。近年てれら悪性リン パ腫について組織学的に分類するのみでなく, 免疫学の発展によりリンパ球の Subclassに 分類する努力が進められ，化学療法の効果が Subclass により異なるとの報告むある。今後 以上のてとを留意して治療法を確站していきた いと考えるが鼻腔悪性リンパ腫には臨床経過の 非常に速い症例があり，検索と平行して治療を 開始せざるをえない場合があり今後の検討が必 要である. 
昰性黒色腫については従米種々の治療法が行 われてきたが，予後の最む琹い悪性腫惕の 1 つ と言われてきた。斎藤ら ${ }^{19}$ や高畑ら ${ }^{201}$ は外科療 法, 化学療法, 免疫療法を併用した治療法によ り效果のあった症例を報告している。しかし， これらの治療法を行って屯予後の改善は難しい ようである. 我々の症例む 2 種の治療法を行い 2 例とも死亡している.今後の治療法の碓立が 必征となる。

\section{まとめ}

1. 当科閒設以来の 9 年間における鼻腔腫陽 34症例の統計的観祭をおてなった。

2. 性比は, 男性に多くみられ, 平均年柃は 50.9才で，琹性症例 $(58,1$ 才）の方が恨症例 （45.3才）よりたかかった。

3. 自覚症状は，良性症例において舅出血が 多く，悪性注例に扣いては舅䦌感が多かった。

4.病理組織は，发性症例に扣いて屯腎性症 例においても多彩であった。

5. 良性症例に损いては全例外科的切除を行 い，現在再発を認めていない.

6. 悪性症例は，上皮性は外科的療法と成射 線療法の併用にて 2 年生存率 $2 / 3=66.7 \%$ で あり，非上皮性は 2 年生存摔 $6 / 9=66.7 \%$ で あった。

7. 墨性リンパ腫, 装性墨色腫については今 後の治療法につつて検剧が必要であると思われ た。

本稿の要旨は第48回耳桀咽峧科臨床学会にて発表し た.

\section{参考文献}

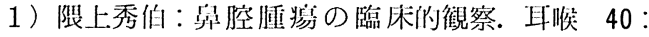
381 388, 1968.

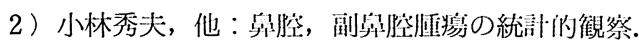
耳展 $3: 470 \sim 477,1960$.

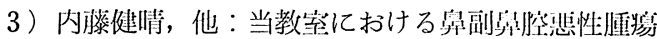
症例の統計的観察. 耳品臨床 $76: 1003 \sim 1011$, 1983.

4）尾崎正義，他：鼻腔，副嶴腔血熘腫25例，耳喉
$49: 53 \sim 58,1977$.

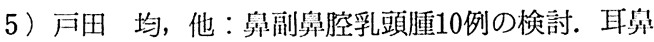
臨床 $76: 1012 \sim 1022,1983$.

6) 御手洗佳代子, 他：奥, 副舀腔粘膜の乳頭腫. 耳 宜 $29: 789 \sim 795,1983$.

7) 礁井康子：柪副邦腔乳頭腫19例の臨床病理学的検 討. 日耳呂 $87: 665 \sim 673,1984$.

8 ）長井克明, 他：上顎洞に発生した hemangiopericytoma の 1 例。耳茄臨床 $76: 1050 \sim$ 1057, 1983.

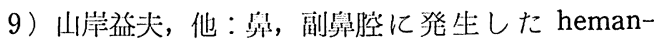
giopericytoma の 2 例. 耳矣 $54: 713 \sim 718$, 1982.

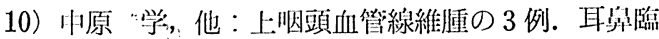
床 $77:$ 1331 1338, 1984.

11）桜井一生，他：舁腔血管線維腫の 2 例.耳鼻臨床 $77:$ 1599 1604, 1984.

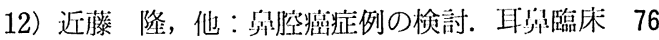
: 1405 1412, 1983.

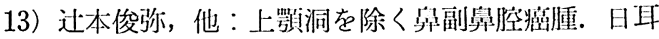
率 $86: 149 \sim 154,1983$.

14）久保隆一，他：固有臭腔より発生した埥性腫崲 14 例について. 耳留 16:3；151 155, 1970.

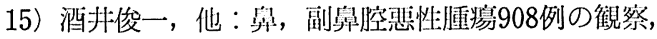
耳鼻 $21 ： 859 \sim 884,1975$.

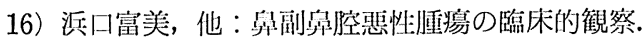
耳多臨床 $74: 956 \sim 971 ， 1981$.

17）消谷忠男，他：細絣肉腫の治燎成績. 耳堠 50 ： 29〜33, 1978.

18）泬口幸吉, 他：曻副率腔悪性リンパ腫 7 症例の検 討. 耳帠臨床 $73: 1447 \sim 1456,1980$.

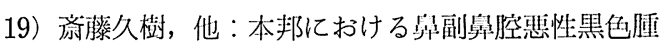
報告例の検討. 日耳厸 $86: 139 \sim 143 ， 1983$.

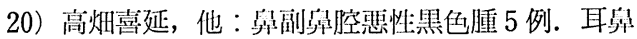
$29: 796 \sim 805,1983$.

21）京 裕治，他：莽腔原発覀性黒色腫 2 症例. 耳展 $28: 185 \sim 188,1985$.

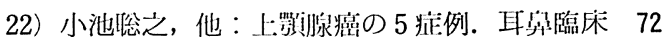
: 759 765, 1976.

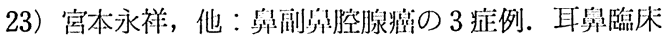
$77: 1585 \sim 1590,1984$.

24) Yamaguchi KT, et al : Inverter papilloma and squamous cell calcinoma. Laryngoscope 
$87: 35 \sim 46,1977$.

25）多田信平 : 今月の症例一若年性血管線維腫. 臨放 $20: 1039 \sim 1040,1975$.

26）白幡雄一, 他：眯科領域血管腫の臨佅像. 耳展 $21: 430 \sim 439,1978$.

27）浅野 登, 他：酉副鼻腔悪性リンパ腫の教室集計
より見た治療指針．耳鼻臨床 $65 ： 1243 〜 1255$ ， 1972.

$$
\left(\begin{array}{l}
\text { 別刷請求先 : 渡邊昭仁 } \\
\text { T078 旭川市西神楽 } 4 \text { 線 } 5 \text { 号 } 3-11 \\
\text { 旭川医科大学耳鼻咽喉科学教室 }
\end{array}\right)
$$

